\title{
A Review on Zakat Payments by Islamic Banks in Malaysia
}

\author{
Samsuwatd Zuha Mohd Abbas, Saliza Sulaiman, and Noorbijan Abu Bakar \\ Universiti Teknologi MARA, Malaysia
}

\begin{abstract}
Zakat plays an important role in the economic development of the ummah. In line with Shariah requirements, the responsibility of paying zakat does not only lie in the Muslim individuals but also businesses, specifically Islamic banks. Islamic Banks exist to fulfil the financial (economic) needs of Muslims within the confines of the Islamic faith. This study aims to analyse the payment of zakat made by the Islamic Banks in Malaysia by firstly, examining the various methods adopted by the Islamic banks and secondly, comparing the existing method of zakat computation. A total of 16 Islamic banks are selected and the financial statements are reviewed from the year 2013 till 2017. The results of the study show that most of the Islamic banks adopted the two methods recommended by JAKIM and both methods show similar results. The results also show an underpayment of zakat by the selected Islamic bank. Further the study found that the detail computation of zakat is not disclosed in the financial statements and hence the study could not identify the adjustments for the zakat computation for all the Islamic banks.
\end{abstract}

Keywords: Zakat, Islamic Banks, Shariah, Method

\section{INTRODUCTION}

Zakat is one of the five pillars of Islam but there are Muslims todays who failed to adhere to this pillar of Islam (zakat). Islamic Law stipulates that zakat should be used to help and support the poor and the needy, to free slaves and debtors, for the cause of Allah and for the musafir as mentioned specifically in Surah At Tawbah Verse 60. As a Muslim, we are required to know how to compute and pay zakat but many Muslims today do not know how to compute zakat properly. This has led to some Muslim underpaying zakat and some who did not pay at all. This matter is of grave concern as the religion has put great emphasis in helping the ummah - the poor and needy. Islam emphasize the need to have an equitable, fair and compassionate ummah.

In achieving this objective of having an equitable, fair and compassionate ummah, the responsibility to pay zakat lies not only on Muslim individuals but also to businesses. One of the most important economic activity encouraged by the prophet Rasulullah (PBUH) is business. Business activity is a one the ways to accumulate wealth and it is subjected to zakat. Various verses from the Quran stressed the necessity for businesses to pay zakat. Among the verses are Surah Al Baqarah Verse 276 and Surah At Tawbah Verse 103. Jawhar (2009) stressed that all kinds of businesses involving goods or services that fulfil the requirements is subject to zakat. Thus zakat is one of the important source of funds to a country's economy.

Further, Abdul Rahman and Awang (2003) state that paying zakat on one's business wealth is based on the Islamic concept of wealth being bestowed by Allah, the real owner of all wealth, as a trust. In addition, the researchers stressed zakat is essential as a social welfare levy imposed to Islamic society's wealthier 
members and more prosperous businesses and thus helps to close the gap between the poor and the rich. Hence, the business that the study is going to analyse is the Islamic banks from the perspective of zakat being paid by these institutions.

According to Ismail, Tohirin and Ahmad (2013), business entities such as Islamic banks are considered as a vehicle to create value added or the wealth of individual. In addition, Ebrahim and Joo (2001) have identified one of the goals of Islamic banks is to foster the growth of the economy of the Muslim by developing financial market, institutions and instruments. In tandem with the above, AIBIM also highlighted that one of the goals of Islamic banks is for equitable distribution of income and wealth. The justification by the above literatures proved that the Islamic banks is the right vehicle to achieve those goals. These goals can be achieved through the payment of zakat by these institutions.

Zakat, therefore, plays an important role in the economic development of the ummah. Islamic banks in Malaysia are required to pay zakat in line with Shariah requirements. As payment of zakat is a requirement to be fulfilled, there are various methods of zakat computation approved by the Majlis Fatwa of the country and hence, this study aims to examine the various methods adopted and the amount of zakat payment made by these Islamic banks. Therefore, the objective of this study is to analyse the payment of zakat made by the Islamic Banks in Malaysia that is to examine the various method adopted by the Islamic banks and to compare the existing method of zakat computation. The study hopes to shed some light on the differences of amount (if any), and whether there is underpaying of zakat payments by these Islamic banks if different methods are adopted by them.

\section{LITERATURE REVIEW}

AAOIFI's FAS 9 define zakat as blessings, purification, increase and cultivation of good deeds. It is called zakat because it blesses the wealth from which it is paid and protected. In Shariah, zakat is an obligation in respect of funds paid for specified type of purpose and for specified categories. Basically, there are two types of zakat, namely zakat on wealth (zakat mal) and zakat on self (zakat fitr). Zakat on self is obliged to all Muslims who live in the whole year of Hijra until the end of Ramadan of that particular year. It is paid in the month of Ramadan before the celebration of Eidul Fitr (1 Syawal). The types of wealth on which zakat must be paid are in the form of monetary wealth in business and employment income, savings, shares, gold, employee provident funds, crops and livestock. Zakat is only obligatory on property possessed for at least one lunar year, though if during the year while the value of the property exceeds the nisab and more property which is held for less than one year is added to the original amount, zakat is paid on the new amount (i.e. zakat is paid on the original property held for one year plus new property held for less than one year, https://www.ethicainstitute.com, (2013). The zakatable wealth should exceed the exemption limit (nisab). Thus, the wealth is zakatable at the rate of $2.5 \%$.

Zakat is an obligatory act to all Muslim because it is one of the five pertinent pillars of Islam. Whoever claims that Zakat is not obligatory and refuses to pay it, is not a Muslim, but a Muslim who refuses to pay Zakat due to stinginess, while affirming its obligation, has committed a great sin for which one will be severely punished. Thus, when a person is liable to pay zakat, a certain percentage of his wealth should be distributed immediately in the correct manner to the poor as stated in the al Quran and Hadis. Thus, those with a certain level of accumulated wealth (nisab \& haul) are 
obligated to pay zakat to purify themselves from the sins of greed (Awang \& Mokhtar, 2011; Sarea \& Hanefah, 2013).

\section{Business zakat in Islamic Banks}

All Muslims are required to pay zakat. Licensed Islamic banks or any banks embedded the word Islam are enmeshed with the obligatory act to pay zakat. In fact, business zakat is obligatory for all types of businesses - be it sole proprietorship, limited partnerships or public companies - so long as Muslims have interests in them (Ismail, Tohirin \& Ahmad, 2013). In fact, zakat is due on anything purchased with the intention of reselling the item, https://www.ethicainstitute.com, (2013). It was further mentioned that tradable goods are zakatable at all stages of production, regardless of whether they are raw material, work in progress or finished product. However, according to Sulaiman (2016), the Islamic bank is an artificial entity. Thus, Islamic banks need not pay zakat. However, Islamic banks are obliged to pay zakat when the law requires the bank to satisfy the zakat obligation, when they are required by their charter or bylaws to satisfy the zakat obligations and when the general assembly of shareholders has passed a resolution requiring Islamic banks to satisfy the zakat obligation.

The basis of computation of zakatable amount slightly differ from one type of zakat to another. Business zakat accounting is established on the basis of ijtihad as agreed by all scholars (Hamat, 2009). AAOIFI's FAS 9 revealed that for business zakat it is obligatory on accounts receivable which are acknowledged by debtors who are able to pay them. It is also obligatory if the debtors refuse to acknowledge the account receivable but there is evidence that they are due and collectible. The standards specify two methods that are net assets method and net invested funds method. Review done by Sarea \& Hanefah, 2013 revealed that
AAOIFI has no authority to impose its standards to be adopted by Islamic Banks, its standards therefore remain voluntary in some countries such as Malaysia. Central Bank of Malaysia (BNM) has no objection to the adoption of the AAOIFI standards but not in contradiction to the national requirements. Basically, there are no specific requirements for the financial statements to show movement of zakat as required by the AAOIFI Zakah FAS 9 standard in Malaysia.

In 2001, the Department of Islamic Development Malaysia (JAKIM) has published a book entitled "Panduan Zakat di Malaysia". According to this book, there are two highly recommended methods of business zakat to be applied. The first method is urfiyyah. This method is also known as the adjusted growth capital which considers the equity of ownership in a particular company and other financial sources. The second method is the syariyyah method. This method is also called the adjusted working capital.

The practice of business zakat measurement in Malaysia involves several methods (Hamat, 2009). The most common methods are Growth Capital Method and Working Capital Method (Awang \& Mokhtar, 2011). According to Mohamed Abdul Wahab et al. (1995), there are three methods of business zakat accounting which are being practiced in various states and institutions in Malaysia, which are the current assets method, current asset and profit from investments method and net working capital method. The latter method was later adopted by Bank Islam Malaysia Berhad (Hamat, 2009). AAOIFI FAS 9 states that zakat is not due on fixed assets (e.g. property, plant and equipment). Business zakat accounting practiced by such institutions can be divided into three methods. First, zakat applies only to current assets as practiced in the state of Kedah, Johor and Kelantan. Secondly, zakat is imposed on the working capital assets as practiced in Perlis. Finally, zakat is imposed on the adjusted 
working capital as practiced in states other than the states of Kedah, Johor, Kelantan and Perlis. However, at this point in time, all states in Malaysia impose zakat on the adjusted working capital (Hamat, 2014).

In so far, the detail information to assess zakat is not properly disclosed in the financial statements especially among the Islamic banks in Malaysia. The uniform and transparent method of zakat payment plays and important role as a benchmark to other institutions while becoming fiscal distribution mechanism for social assistance to grant better education, health care, housing, and public transportation for Muslims in a welfare state and creates a balanced growth cycle (Yusuf, 2013). The most crucial aspect to look into is determining the zakatable items/assets, the method to select the basis of zakat and the formula of zakat calculation, within an Islamic bank entity. From practices exposed in this paper, only in a few countries, such as Bahrain, United Arab Emirates and Malaysia implemented business zakat in Islamic banks. In the first two countries, zakatable items are clearly mentioned, i.e. the banks' reserve, and retained earnings, while for Malaysia, no specific items are explicitly mentioned (Sarea \& Hanifah, 2013). Further, a study by Ismail, Tohirin \& Ahmad (2013) revealed that among Islamic banks in Malaysia, it is unclear from which zakatable items the calculated zakat be applied. Among other problems arising in implementing business zakat are its chargeability and its calculation, determination of zakat base and zakat eligibility of assets and liabilities.

Study by Hamat (2009) found that all zakat scholars in Malaysia agreed that adjusted working capital should be the method to be used, however, other methods cannot be denied. In addition, they expressed the same opinion that business zakat accounting method should not be rigid, therefore, it could be changed according to the requirement of the current situation. Ultimately, zakat is payable on the business income irrespective of whether profit has been earned or not. Even for businesses that suffer losses but still has a positive working capital, zakat is still payable.

\section{METHODOLOGY OF STUDY}

The population of our study consists of Islamic Banks operating in Malaysia. Our sample was based on the list of Islamic financial institutions from the Bank Negara Malaysia (BNM) List of Licensed Islamic Financial Institutions in Malaysia and there are 16 such institutions in the country. Among the 16 institutions, 11 banks are locally incorporated and they are Bank Islam, Maybank Islamic, Ambank Islamic, Bank Muamalat, Affin Islamic, Alliance Islamic, CIMB Islamic, Public Islamic, RHB Islamic and Hong Leong Islamic and MBSB Bank. The five foreign banks are Standard Chartered Saadiq, Kuwait Finance, OCBC Al-Amin, HSBC Amanah and Al Rajhi Bank.

These study encompasses the examination of specific financial statements and a content analysis of specific reports in the published annual reports of these Islamic banks for the years 2013 until 2017. The period of 2013 to 2017 was chosen as the Financial Services Act (FSA) and the Islamic Financial Services Act (IFSA) came into force on 30 June 2013 replacing the repealed Islamic Banking Act 1983 (IBA). From the total number of 16 Islamic Banks, data was only collected form 15 banks as the financial statements of Ambank Islamic for the years of 2013, 2014 and 2017 were not accessible through its website. In examining these Islamic banks, two specific statements were reviewed and they were the Statement of Financial Position and Statement of Income.

According to Hamat, 2009, the measurement of business zakat is based on the data from the statement of financial position. Awang and Abdul Rahman 
(2003) in their study on zakat measurement highlighted two approaches namely the Growth Model method and the Working capital model. The Growth
Model method also known as Adjusted Growth Capital method considers the equity of ownership. The formula is as below:

\section{Equity + Long term equity - Fixed Asset - Non Current Asset +/- Adjustments.}

The latter approach namely the Working Capital Model considers current assets by deducting currents liabilities and taking into account the necessary adjustments (Hamat, 2009). The formula is as below:

\section{Current Asset - Current Liabilities +/- Adjustments}

For the collection of the above data, the Statement of Financial position is examined. Items in the financial statements collected are:

\section{Statement of Financial Position \\ 1 Total Assets \\ 2 Fixed Assets (Property, Plant and Equipment) \\ 3 Total Liabilities \\ 4 Share Capital \\ 5 Reserves/Share Premium/Retained Profits/Other Reserves \\ 6 Total Equity}

Additionally, the Income Statement of these Islamic Banks were reviewed for purposes of collecting the data on Net Profit before Tax and Zakat and the Zakat.

\section{Statement of Income}

1 Profit before Tax and Zakat

2 Zakat

Apart from the above, a content analysis was carried out by examining firstly, the Shariah Committee Report in the Annual Reports of these Islamic banks to identify the policy adopted by these banks as to the specific approach taken of either the Growth Model or Working Capital Model. Secondly, the Notes to the Financial Statements specifically on the Summary of Significant Accounting Policies were examined to identify further information on zakat payment and computation. Content analysis has been widely employed in prior studies to measure voluntary and mandatory disclosures in annual reports (e.g. Hackston \& Milne, 1996; O’Donovan, 2002; Clemens \& Douglas et al., 2006).

\section{RESULTS AND ANALYSIS}

The Shariah Committee Report of the Islamic Banks were scrutinized and various statements on Zakat and Zakat obligations were gathered. Examples of the excerpts from the Shariah Committee reports are as below:

Table 1. Summary of Excerpt from the Shariah Committee Report

The bank pays zakat on its business. The banks does not pay zakat on behalf of the shareholders and depositors.-Alliance Islamic

In the financial year under review, pursuant to the Bank's Zakat Policy, the Bank has fulfilled its obligation to pay zakat on its business to the federal zakat body and other eligible recipients selected by the Bank and the zakat is computed using growth capital method. The zakat body had refunded a portion of the zakat paid and had appointed the Bank to act as their agent (wakeel) to 
distribute to eligible beneficiaries (asnaf) on behalf of the zakat body. - Bank Muamalat

The calculation of zakat is in compliance with Shariah principles. The zakat fund is distributed through various channels i.e. States Zakat Collection Centre, non-govermental organization and individuals under asnaf categories of poor, needy, amil, riqab, gharimin and fisabilillah.- Affin Islamic

All earnings that have been realised from sources or by means prohibited by the Shariah principles that we discovered have been considered for disposal to charitable causes. - Al-Rajhi Bank

In the financial year, the Bank has made a zakat payment on its business to state zakat authorities and the zakat is computed using the growth capital method. The beneficiaries of the zakat fund were Lembaga Zakat Selangor, International Islamic University Malaysia (IIUM) Endowment Fund, Lembaga Zakat Kedah, Universiti Teknologi Mara (UiTM) Zakat Centre and Pertubuhan Kebajikan Islam Malaysia (PERKIM). - OCBC Al Amin

The financial statements of the bank for the year ended ........ together with the calculation of zakat disclosed to us are in compliance with the shariah rules and priciples. - Maybank Islamic

The Bank does not pay zakat on behalf of the shareholders or depositors-Standard Chartered Saadiq

Standard Chartered Saadiq Berhad during the year ended 31 December 2017 is not required to pay zakat because its shareholder is non-Muslim.

The Bank is not required to pay zakat for the financial year ended 31 December 2017 because its shareholder has no obligation to pay zakat. - HSBC Amanah

Based on the examination of the audited financial statements of the Islamic banks, the study found that there are other methods adopted instead of the two commonly mentioned methods (Growth Asset Method and Net Assets Method) advocated by the Shariah scholar as follows:

Table 2. List of Islamic Banks and Method Adopted by the Banks

\begin{tabular}{llll}
\hline No & \multicolumn{1}{c}{ Islamic Banks } & *Majority ownership & Zakat Methods Adopted \\
\hline $\mathbf{1}$ & Affin Islamic Bank Bhd & Government owned & Net Assets Method \\
$\mathbf{2}$ & $\begin{array}{l}\text { Al Rajhi Banking \& } \\
\text { Investment Corporation } \\
\text { (Malaysia) }\end{array}$ & Foreign bank & Paid by parent company \\
$\mathbf{3}$ & Alliance Islamic Bank Bhd & Foreign Bank & Growth capital method. \\
$\mathbf{4}$ & AmBank Islamic Bhd & $\begin{array}{l}\text { Government \& Family } \\
\text { Owned }\end{array}$ & $\begin{array}{l}\text { Financial statement not } \\
\text { available }\end{array}$ \\
$\mathbf{5}$ & Bank Islam Malaysia Bhd & Government & Growth capital method \\
$\mathbf{6}$ & Bank Muamalat Malaysia & Government \& Individual & Shareholders' funds growth \\
\hline
\end{tabular}




\begin{tabular}{|c|c|c|c|}
\hline & Bhd & & method \\
\hline 7 & CIMB Islamic Bank Bhd & Government & Average growth method \\
\hline 8 & $\begin{array}{l}\text { HSBC Amanah Malaysia } \\
\text { Bhd }\end{array}$ & Foreign & $\begin{array}{l}\text { No zakat payment made due to } \\
\text { no muslim equity muslim. }\end{array}$ \\
\hline 9 & $\begin{array}{l}\text { Hong Leong Islamic Bank } \\
\text { Bhd }\end{array}$ & Family owned & Net assets method \\
\hline 10 & $\begin{array}{l}\text { Kuwait Finance House } \\
\text { Malaysia Bhd }\end{array}$ & Foreign & Paid by parent company \\
\hline 11 & MBSB Bank Bhd & Government & $\begin{array}{l}\text { Method not disclosed in the } \\
\text { financial statement }\end{array}$ \\
\hline 12 & Maybank Islamic Bhd & Government & Average growth method \\
\hline 13 & OCBC Al Amin Bank Bhd & Foreign & $\begin{array}{l}\text { Growth capital method (zakat } \\
\text { paid based on Muslim equity } \\
\text { portion) }\end{array}$ \\
\hline 14 & Public Islamic Bank Bhd & Family owned & Profit and loss method \\
\hline 15 & RHB IslamicBank Bhd & Government & Working capital method \\
\hline 16 & $\begin{array}{l}\text { Standard Chartered Saadiq } \\
\text { Bhd }\end{array}$ & Foreign & $\begin{array}{l}\text { No zakat payment made due to } \\
\text { no muslim equity muslim. }\end{array}$ \\
\hline
\end{tabular}

*M Abbas (2012)

The other methods adopted include the Profit Loss Method, Average Growth Method and Shareholders' Funds Growth Method. The Islamic banks that adopted the different methods were Bank Mualamat (Shareholders' Funds Growth Method), CIMB Islamic Bank (Average Growth Method), Maybank Islamic (Average growth method) and Public Islamic Bank. There are two foreign banks namely Al Rajhi and Kuwait Finance House that their zakat was been paid by their parent company.

A Foreign controlled bank namely OCBC Al Amin pay zakat based on the Muslim equity of the bank. While another two foreign banks did not pay zakat since the owners are non-muslim and this in line with the Ijma of the Shariah Scholar (Mohamad and Trakic, 2013). There is only one Islamic bank-MBSB Bank Bhd did not mention the method of zakat payment that the bank adopted. Thus based of these findings most of the Islamic banks adopted two highly recommended methods by JAKIM on business zakat that is urfiyyah method or is also known as the adjusted growth capital method which considers the equity of ownership in a particular company and other financial sources. While the second method is the syariyyah method or adjusted working capital method that considers current assets and deducts current liabilities.

This study managed to compute the zakat made by Bank Islam for the fiveyears period from 2013 until 2017 based on the most complete data available. Most of the Islamic banks' published data are not readily available. Furthermore, most of the Islamic banks are not listed entities. Based on the reviewing of the financial statements of the Islamic banks we found that the detail information to derive at the adjustments amount using Growth Capital method is not available in the financial statement nor in the notes to the accounts. The figures for some of the adjustments are only mentioned in the corporate information and the bank activities during the year but there was no conclusive statement that the figures are the total amount for each of the adjustment items.

Moreover, none of the Islamic banks disclosed the details computation in arriving to the amount of zakat that they paid. Unlike tax, all information is disclosed specifically in the notes to the 
accounts. Thus, due unavailability of these information, we decide to exclude adjustments in our computation. Although, we exclude the adjustments, the above analysis revealed slightly the same result when using both methods. This is consistent with the study conducted by Hamat (2009), whereby both methods resulted into insignificant differences in arriving at the zakat amount. The computation of these differences is shown in Table 3.
Based on the result from Table 3, the study found that the zakat payment made by the bank is significantly lower as compared to the calculation done by this study based on the two alternative methods proposed by scholars that are growth capital method and working capital method. The percentage of the differences range significantly between $384 \%-759 \%$ which is lower than the actual zakat paid, with the amount ranging between RM48,997 - RM100,104 for the two methods. This computation excluded adjustments due to insufficient details information required as mentioned above. AAOIFI's FAS 9 specified two methods that are net assets method and net invested funds method. Even if the simple net assets method was used, the minimum zakat payment should be RM61,744 instead of RM12,747. 
Table 3: Zakat Computation for Bank Islam using Growth Method and Working Capital Method

\begin{tabular}{|c|c|c|c|c|c|}
\hline \multirow{2}{*}{ ZAKAT METHOD } & 2013 & 2014 & 2015 & 2016 & 2017 \\
\hline & \multicolumn{5}{|c|}{ RM'000 } \\
\hline Zakat amount (Published) & 12,568 & 12,747 & 8,703 & 12,851 & 13,323 \\
\hline \multicolumn{6}{|c|}{ Growth Method: } \\
\hline 1. Net Worth of Current Assets & $3,313,896$ & $2,469,768$ & $2,989,132$ & $3,622,206$ & $4,409,323$ \\
\hline 2. Adjustments & - & - & - & - & 127,755 \\
\hline Total & $3,313,896$ & $2,469,768$ & $2,989,132$ & $3,622,206$ & $4,537,078$ \\
\hline Zakat based on CG Method: & 82,847 & 61,744 & 74,728 & $\mathbf{9 0 , 5 5 5}$ & 113,427 \\
\hline $\begin{array}{l}\text { Percentage of Difference for Zakat } \\
\text { (Actual Versus CG Method) }\end{array}$ & $559 \%$ & $384 \%$ & $759 \%$ & $605 \%$ & $751 \%$ \\
\hline \multicolumn{6}{|c|}{ Working Capital Method: } \\
\hline 1. Current Assets & $41,277,513$ & $44,236,020$ & $47,916,853$ & $54,059,975$ & $56,118,903$ \\
\hline 2. Current Liabilities & $37,963,617$ & $41,766,252$ & $44,927,721$ & $50,451,864$ & $51,709,580$ \\
\hline Net worth of Current Assets & $3,313,896$ & $2,469,768$ & $2,989,132$ & $3,608,111$ & $4,409,323$ \\
\hline Zakat based on WC Method: & 82,847 & 61,744 & 74,728 & 90,203 & 110,233 \\
\hline $\begin{array}{l}\text { Percentage of Difference for Zakat } \\
\text { (Actual Versus WC Method) }\end{array}$ & $559 \%$ & $384 \%$ & $759 \%$ & $602 \%$ & $727 \%$ \\
\hline
\end{tabular}




\section{CONCLUSION}

From the 16 Islamic banks, twelve Islamic banks paid zakat and more than half of these banks (eight banks) adopted the recommended method by JAKIM namely the urfiyyah method or also known as the adjusted growth capital method and the syariyyah method or adjusted working capital method. While another four of the Islamic banks adopted other methods approved by their Shariah Committee. Secondly the study found that the zakat payment made by the bank is significantly lower as compared to the calculation done by this study based on the two recommended methods stated above. In analysing the zakat payment in the financial statement, the study also found that all the Islamic banks did not disclose the detail computation in arriving to the zakat payment. This practice is totally in contract with the tax computattion that is detailed out in the financial statement specifically in the notes of the account.

\section{Recommendations}

This study raises several suggestions to Islamic banks for further considerations. Firstly, it is recommended that the Islamic banks should disclose the details computation of zakat in the notes of account of the banks for transparency and easy retrieval to recompute the zakat payment. This is important to for the regulators, financial analyst and others to check and balance the zakat disclosed in the financial statements. Further, the Islamic banks should pay more zakat (by not taking into accounts some of the adjustments) in order to meet their objective of Maslahah of ummah namely as socio-economic justice and equitable distribution and last but not least the Islamic banks should be given the privileged to opt in paying zakat instead of tax in order to meet their objective of Maslahah of ummah namely as socio- economic justice and equitable distribution.

\section{REFERENCES}

Accounting and Auditing Organization for Islamic Financial Institutions (AAOIFI), Financial Accounting Standards (FAS) 9 - Zakat

Awang and Abdul Rahman (2003). Assessing Business Zakat: Between Theory \& Practice, National Accounting Research Journal, 10, 1.

Awang, R., and Mokhtar, M.Z., Technical Comparison Between Business Zakat And Tax on Business Income in Malaysia, Malaysian Accounting Review, Vol. 10 No. 2, 13-25, 2011

Buletin JAWHAR Vol. 2/2009, http://intranet.jawhar.gov.my/pener bitan/public/page_detail.php?id=82

Clemens, B., and Douglas, T. J. (2006). Does coercion drive firms to adopt Voluntary' green initiatives? Relationships among coercion, superior firm resources, and voluntary green initiatives. Journal of Business Research, 59, 483-491.

Ebrahim, M.S., Tan, K.J.,(2001) Islamic Banking in Brunei Darussalam, International Journal of Social Economics. Vol 28 Issue: 4, pp. 314-337, htpps://doi.org/10.1108/030682901 10357708

Hackston, D., and Milne, M. J. (1996). Some Determinants of Social and Environmental Disclosures in New Zealand Companies. Accounting, Auditing and Accountability Journal, 9(1), 77-108.

Hamat, Z. (2009). Business Zakat Accounting and Taxation in Malaysia, paper presented on Conference on Islamic Perspectives on Management and Finance, 
University of Leicester, United Kingdom.

Hamat, Z., (2014). Sustainable Zakat Accounting in Malaysia: An Analysis, Mediterranean Journal of Social Sciences, Vol. 5, No.19, August 2014.

Haniffa, R. M. and M. A. Hudaib: (2007), Exploring the Ethical Identity of Islamic Banks via Communication in Annual Reports: Journal of Business Ethics (2007) 76:97-116 Springer $2007 \quad$ DOI 10.1007/s10551-006-9272-5.

Ismail, A.G. and Tohirin, A., Ahmad, M.A.J.,(2013) Debate on Policy Issues in the Field of Zakat on Islamic Bank Business. IRTI Policy Paper, Islamic Research and Training Institute, PP\#1435-03.

Jaelani, A., (2016) Zakat Accounting: Metaphor and accounting treatment for business organization., Munich Personal RePEc Archive, https: //mpra.ub.uni-muenchen.de/74782, MPRA Paper No. 71782, 28 October 2016

Md Razak, M.I., Omar, R., Ismail, M., Amir Hamzah, A.S., Hashim, A., (2013) Overview of Zakat Collection in Malaysia: Regional Analysis, American International Journal of Contemporary Research, Vo. 3 No. 8: August 2013.

Mohd Abbas, S., Abdul Rahman, R., Mahenthiran, S., (2009) Ultimate Ownership and Performance of Islamic Financial Institutions. Asian Finance Association Conference, July 2009.

Mohd. Noor, M.S., (2017) Indicators of Business Zakat amongst Small Business: Concept and Contemporary Needs. International Journal of Academic Research in Business and Social Sciences, Vol. 7, No. 6, 2017. ISSN: 2222-6990.

Mohammad, A.H. and Trakic, A., (2013). Critical Appraisal of the Companies' Obligations to Pay
Zakat in the Malaysian Context. Research Gate.

Mohammed Sarea, A., (2013) Accounting Treatment of Zakah: Additional Evidence from AAOIFI, Journal of Islamic Banking and Finance, Vol. 1 No. 1, December 2013.

Mohammed Sarea and A., Mohd Hanefah, M., (2013) The need of accounting standards for Islamic financial institutions: Evidence from AAOIFI, Journal of Islamic Accounting and Business Research, Vol.4 No. 1, 2013, pp 64-76

Muller, D.M., (2017) From Consultancy to Critique: The "Success Story" of Globalized Zakat Management in Malaysia and its Normative Ambiguities. Globalizations, Vol.14, No. 1, 81-98, http://dx.doi.org/10.1080/1477731. 2016.1200309.

Mohammad, M.O. and Shahwan, S., (2013) The Objective of Islamic Economic and Islamic Banking in light of Maqasid Al-Shariah: A Critical Review, Middle East Journal of Scientific Research 13 (Research in Contemporary Islamic Finance and Wealth Management), pp 75-84.

O’Donovan, G. (2002). Environmental Disclosures in the Annual Report: Extending the Applicability and Predictive Power of Legitimacy Theory. Accounting, Auditing and Accountability Journal, 15(3), 344371.

Said Bouheraoua (2012) Zakah obligations on Islamic financial institutions. International Shari'ah Research Academy for Islamic Finance Research Paper; No.34/2012.

Sulaiman, M., and Mohd Ariffin, N., (2016) Accounting for Islamic Banks, International Islamic University Malaysia.

Shamsudin, N. and Mohammed, M.O., (2015) Performance Direction 
towards Performance

Achievement: Case on Local Islamic Banks in Malaysia, Journal of Economics, Business and Management, Vol2, No. 9, September 2015.

Yusuf, M.B.O., \& Derus, A.M. (2013). Measurement model of corporate zakat collection in Malaysia: A testof diffusion of innovation theory. Humanomics, 29(1), pp.61.

Zakat Q \& A Handbook, (2013), Ethica Institute of Islamic Finance, www.Eticalinstitute.com.

Zulfikar, M., (2011) Zakah: According to the Quran and Sunnah. Riyadh: Maktaba Dar-us-Salam.
Samsuwatd Zuha Mohd Abbas

Universiti Teknologi MARA

Malaysia

zuha@salam.uitm.edu.my

Saliza Sulaiman

Universiti Teknologi MARA

Malaysia

saliza.sulaiman@salam.uitm.edu.my

Noorbijan Abu Bakar

Universiti Teknologi MARA

Malaysia

noorbi374@salam.uitm.edu.my 